\title{
The Effect Of Individual Counseling Toward Knowledge, Attitude and Behavior of Pregnant Woman about The Ante Natal Care in East Ciputat Public Health Center Year 2016
}

\author{
Wahyu Arifiyanti Haryoso, Mustika Anggiane Putri, Marita Fadhilah, Taufik Zain, Risahmawati \\ Faculty of Medicine and Health Sciences, Syarif Hidayatullah State Islamic University \\ Indonesia
}

\begin{abstract}
The rate of maternal and infant mortality are still high in Indonesia, one of the causes is the high rate of low birth weight. There are many etiology of low birth weight, and most of them are preventable if pregnant women do antenatal care (ANC) during pregnancy. Aim of this research is to determine the knowledge, attitudes and behavior of pregnant woman at East Ciputat Public Health Center (Puskesmas) about ANC to take care their pregnancy until birth. Experimental design with pretest and posttest study type. The research was conducted in polyclinic of mother and child Health in East Ciputat Puskesmas, Pamulang, South Tangerang during August 2016. The population are pregnant woman who control to Puskesmas Ciputat Timur in August 2016. The total sample are 31 respondents, with consecutive sampling and analyze by Wilcoxon. Result: The results after we give individual counseling, we have been getting a decline of the respondents who have low knowledge $22.6 \%$, increasing of the respondents that have moderate knowledge $3.2 \%$, and $19.4 \%$ for the increasing of the respondents with high knowledge. We have 31 respondents with positive attitude which is increase $16.1 \%$. We got decreasing $19.4 \%$ respondents who have negative behavior, and increasing $19.4 \%$ respondents who have positive behavior. The "P" value for the knowledge, attitude and behavior is $0.002 ; 0.000 ; 0.002$. This shows that the individual counseling to the respondents is meaningful.
\end{abstract}

Keywords: Individual Counseling; Knowledge; Attitude; Behavior; Pregnant Woman; ANC; Low Birth Weight

\section{INTRODUCTION}

The number of maternal and neonatal mortality rate are still high. From the demography of health survey in Indonesia in $2012,59,4 \%$ the number of dead baby and $47,5 \%$ for neonatal dead (in the first 28 days) 1 . Low baby weight born is one of causes the death of neonates which is $27 \% 2$. Every causes can be decreased if mother know how to care baby when she pregnant.2. In the world the case about low baby weigh born is about 23.8\%3. In 2002 the number of low baby weight born in South East Asia is $14.6 \%$, which is 9\% in Indonesia.4

Antenatal Care (ANC), which are done habitually, could decrease the number of maternal and neonatal mortality. The purpose of ANC is to care daily about the pregnancy, by mother it self after got training from the doctor, or instruction. By caring and controlling the pregnancy routinely, we will see every risk, that happen to the mother, so we will get every problems and take care of it fast.

\section{METHOD}

This research is experimental by pretest posttest study to know how the knowledge attitude and behavior of the mother before and after conference. We are looking for the respondent in poli KIA Puskesmas Ciputat Timur, Tangerang Selatan during august 2016 the population target is pregnant woman and we took every nation that came to puskesmas. We use consecutive sample, with inclusion criteria is pregnant woman less than 34 weeks or 8 month pregnancy when we do pre-test, health in physical and soul and the exclusion criteria is the mother who not come to the puskesmas again when we do post test or rejected or cannot be contact. the total sample we used pair numeric ana-lytic and we got 13 respondent. and we used 31 sample to this research. With independent variable is the pregnant mother and dependent is the knowledge attitude and behaviour of the patient the statistic analysis we used by wilcoxon.

We collect the pregnant woman that came to Puskesmas, and do permission to do the research and they will answer the pretest and will do post test 1 month later when they are control to the poly.

\section{RESULT AND DISCUSSION}

After pretest and posttest we analyzed the data that most of them have moderate knowledge and after the conference we got 58\% respondent increasing their category of knowledge with $p$ value 0.002 . It means that by the conference we can give more information to the mother and significant to increasing their knowledge.

While the mother have good knowledge we will see how attitude they show according the knowledge they have. Before conference only 5 respondents that have negative attitude, after 3 months later all of them change to be a positive attitude. It shown that they have enough knowledge to increasing the attitude to be $100 \%$. 
TABLE 1. KNOWLEDGE RESPONDENT

\begin{tabular}{|c|c|c|c|c|c|}
\hline $\begin{array}{c}\text { knowledge } \\
\text { category }\end{array}$ & $\begin{array}{c}\text { Respondent } \\
\text { pretest }\end{array}$ & $\begin{array}{c}\text { Knowledge } \\
\text { category }\end{array}$ & $\begin{array}{c}\text { Respondent } \\
\text { posttest }\end{array}$ & $\begin{array}{c}\text { Persentage } \\
\%\end{array}$ & $\begin{array}{c}P \\
\text { value }\end{array}$ \\
\hline Low & 11 & Low (0-49) & 2 & 18,2 & 0,002 \\
\hline \multirow[t]{3}{*}{$(0-49)$} & & Moderate (50- & & & \\
\hline & $(35,5 \%)$ & 74) & 7 & 63,6 & \\
\hline & & High (75-100) & 2 & 18,2 & \\
\hline Moderate & 16 & Low (0-49) & 2 & 12,5 & \\
\hline \multirow[t]{3}{*}{$(50-74)$} & $(51,6 \%)$ & Moderate (50- & & & \\
\hline & & 74) & 9 & 56,2 & \\
\hline & & High (75-100) & 5 & 31,2 & \\
\hline High & 4 & Low (0-49) & 0 & 0 & \\
\hline \multirow[t]{3}{*}{$(75-100)$} & $(12,9 \%)$ & Moderate (50- & & & \\
\hline & & 74) & 1 & 20 & \\
\hline & & High $(75-100)$ & 3 & 80 & \\
\hline
\end{tabular}

TABLE 2. ATTITUDE RESPONDENT

\begin{tabular}{cccccc}
\hline \hline $\begin{array}{c}\text { Category } \\
\text { Attitude }\end{array}$ & $\begin{array}{c}\text { Respondent } \\
\text { Pretest }\end{array}$ & $\begin{array}{c}\text { Category } \\
\text { Attitude }\end{array}$ & $\begin{array}{c}\text { Respondent } \\
\text { Posttest }\end{array}$ & $\begin{array}{c}\text { Persentase } \\
\%\end{array}$ & P value \\
\hline \hline Negative & 5 & $\begin{array}{c}\text { Negative } \\
(0-64)\end{array}$ & 0 & 0 & 0.000 \\
& 5 & $\begin{array}{c}\text { Positive } \\
(0-64)\end{array}$ & & & \\
& $(16,1 \%)$ & $\begin{array}{c}(65-100) \\
\text { Positive }\end{array}$ & 5 & 100 & \\
& 26 & $\begin{array}{c}\text { Negative } \\
(0-64)\end{array}$ & 0 & 0 & \\
$(65-100)$ & & Positive & & & \\
& $(83,9 \%)$ & $(65-100)$ & 26 & 100 & \\
\hline
\end{tabular}

TABLE 3. BEHAVIOR RESPONDENT
There are many mothers that have good knowledge but not goods in implementing their knowledge as behavior. So after 3 month we will see how many mother that try to change their

\begin{tabular}{|c|c|c|c|c|c|}
\hline $\begin{array}{l}\text { Category } \\
\text { behavior }\end{array}$ & $\begin{array}{c}\text { Respondent } \\
\text { pretest }\end{array}$ & $\begin{array}{l}\text { Category } \\
\text { behavior }\end{array}$ & $\begin{array}{c}\text { Respondent } \\
\text { posttest }\end{array}$ & $\begin{array}{c}\text { Persentase } \\
\%\end{array}$ & P value \\
\hline \multirow[t]{2}{*}{ Negative } & & Negative (0- & & & 0,002 \\
\hline & 26 & 49) & 17 & 65,4 & \\
\hline \multirow[t]{2}{*}{$(0-49)$} & & Positive (50- & & & \\
\hline & $(83,9 \%)$ & 100) & 9 & 34,6 & \\
\hline \multirow[t]{2}{*}{ Positive } & & Negative (0- & & & \\
\hline & 5 & 49) & 3 & 60 & \\
\hline \multirow[t]{2}{*}{$(50-100)$} & & Positive (50- & & & \\
\hline & $(16,1 \%)$ & 100) & 2 & 40 & \\
\hline
\end{tabular}

behavior to be positive. And we got that number of positive behavior increasing, but some of them still in the negative behavior.

\section{CONCLUSION}

After the conference we got increasing of respondent knowledge $58 \%$, increasing the attitude of respondent $100 \%$ and increasing behavior of respondent $35 \%$ with $\mathrm{p}$ value knowledge: attitude: behavior $0.002: 0.000: 0.002$.

\section{REFERENCES}

[1] Hukormas. Reduce Child Mortality Rate Remains Far from Set Target Ministry of Health (Mengurangi Angka Kematian Anak Masih Jauh Dari Target yang Ditetapkan). KEMENKES RI. 2014. Pada URL http://www.gizikia.depkes.go.id/mengurangi-angka-kematian-anakmasih-jauh-yang-ditetapkan/ . Diakses pada 23 Februari 2015

[2] Angriani, Sri. Amelia Fransisca. Jamila Kasim. Correlation between Kangaroo Mother Care and body temperature (Hubungan Antara Metode Kangaroo Mother Care (KMC) Terhadap Suhu Tubuh BBLR Di RSKD Ibu Dan Anak Pertiwi Makassar). Makassar : Indonesia Scientific Journal Data Base. 2014. Dari URL http://library.stikesnh.ac.id/files/disk1/9/e-li-

brary\%20stikes\%20nani\%20hasanuddin--sriangrian-427-1-4114712_2.pdf . Di akses pada 5 oktober 2014

[3] [WHO. Fetomaternal nutrition and low birth weight. -. Pada URL http://www.who.int/nutrition/topics/feto_maternal/en/ . Di akses pada 23 Februari 